ISSN 1676-3742

\title{
A Celebração Litúrgica como uma Mística Sacramental
}

\author{
Luiz Fernando R. Santana
}

\section{Resumo}

A finalidade de nossa pesquisa é tentar mostrar que a missão do Espírito Santo após o evento de Pentecostes é fundamentalmente aquela de determinar a qualidade da oração cristã e, mais precisamente, da oração da Igreja. Tal como fez com Jesus, o Espírito nos concede a capacidade de nos dirigir a Deus como $A b b a$, tornando-se, dessa maneira, o agente que nos configura à oração do Filho de Deus e nos torna partícipes da ininterrupta intercessão e do perene louvor de Jesus ao Pai. É do nosso interesse mostrar ainda que, em última análise, a espiritualidade cristã é essencialmente uma mística sacramental.

Palavras-chave: Espírito Santo, Oração, Igreja, Espiritualidade, Mística.

\section{Abstract}

The purpose of our research is try to show that the mission of the Holy Spirit after the event of Pentecost is essentially determine the quality of Christian prayer, and more specifically, the prayer of the Church. As it did with Jesus, the Spirit gives us the ability to name God as $A b b a$ and in this way, he also is the agent which conforms us to the prayer of the Son of God and makes 
us participants of continuous intercession and praise of the perennial Jesus to the Father. Our interest is also to show that Christian spirituality is essentially a sacramental mystic.

Keywords: Holy Spirit, Prayer, Church, Spirituality, Mystic.

\section{Introdução}

"Vem a hora - e é agora - em que os verdadeiros adoradores adorarão o Pai em Espírito e Verdade" (Jo 4,23). Esta profunda declaração feita por Jesus à mulher Samaritana nos mostra que "Deus é Espírito" e os que se lançam na aventura de ser adoradores de Deus, devem aprender a fazê-lo em "Espírito e Verdade"1.

A partir dessa declaração bíblica tentaremos mostrar aquilo que especifica a oração cristã como tal: o fato de ser ela um "culto espiritual", isto é, realizado na força do Espírito Santo, o qual não cessa de vir ao nosso encontro por meio de Jesus. De fato, segundo a revelação bíblica, o Espírito Santo é o protagonista da oração cristã, o "Orante" por excelência, o único capaz de transfigurar a existência do homem numa oferenda e num culto agradável a Deus. Nesse sentido, poderíamos afirmar que o processo de aprendizagem da oração quer ser, antes de mais nada, um exercício e uma abertura para o acolhimento do dom do Espírito Santo.

A necessidade de se abraçar o Espírito Santo como o "Orante" em nós e o "Dom-oração" se apóia na experiência de nossa debilidade e impotência, tal como o apóstolo Paulo formula em Rm 8,26: "Assim também o Espírito socorre a nossa fraqueza. Pois não sabemos como pedir como convém; mas o próprio Espírito intercede por nós com gemidos inefáveis"2. Somente o Espírito conhece entranhadamente a impotência da criatura que geme numa contínua busca da face de Deus. Por essa razão, Ele mesmo quer ser o apoio da nossa debilidade e a força da nossa impotência, a fim de que nossa incapa-

\footnotetext{
${ }^{1}$ Cf. PANIMOLLE, S.A., "La Adorazione di Dio in Spirito e Verità". In: AA.VV., Spirito Santo e Liturgia - Atti della XII Settimana di Studio dell'Associazione Professori di Liturgia, Valdragone (S.Martino), 22-26 agosto 1983, Casale Monferrato, Marietti, 1984, pp. 11-22.

${ }^{2}$ A esse respeito é oportuno conferir o n. 26 da Instrução Geral à Liturgia das Horas: "O mesmo Espírito Santo que está em Cristo, em toda a Igreja e em cada um dos batizados realiza a unidade da Igreja orante. O mesmo Espírito vem "auxiliar a nossa fraqueza" e "advoga por nós com gemidos inefáveis" $(\mathrm{Rm}$ 8,26) [...] - SAGRADA CONGREGAÇÃO PARA O CULTO DIVINO, Instrução Geral à Liturgia das Horas, Rio de Janeiro, Lumen Christi, 1982.
} 
cidade radical não se torne mudez diante d'Aquele que nos ama e nos acolhe como somos e com tudo o que trazemos em nós.

Cabe ao Espírito Santo determinar essencialmente a qualidade da oração cristã. Tal verdade pode ser muito bem ilustrada por Paulo, que, como mestre e testemunha de oração segundo o modelo bíblico, mostra-nos que o Espírito Santo é quem nos faz chamar Deus de $A b b a$, outorgando-nos, assim, a condição de "filhos de Deus" (cf. Rm 8,14-16). Concedendo-nos tal dom, ou seja, a capacidade de nos dirigir ao Deus de Jesus como Abba, o Espírito torna-se o agente que nos configura à oração do Filho de Deus e nos torna partícipes da ininterrupta intercessão e do perene louvor de Jesus ao Pai. O autor da carta aos Hebreus nos afirma que Cristo, por meio do Espírito, se ofereceu ao Pai como um sacrifício vivo (cf. Hb 9,14). Isso nos leva a considerar que, obedecendo incondicionalmente ao seu Deus e por ele se oferecendo, Jesus, ao longo de sua existência terrena, experimentava visceralmente o amor de seu $A b b a$, ainda que isso se verificasse na contradição do sofrimento e da morte: "Deus meu, Deus meu, por que me abandonaste?" (Mt 27,46) . $^{3}$

Ponto culminante da revelação que Jesus faz de Deus é a própria entrega, em forma de herança, do seu "Abba amado" aos seus apóstolos e discípulos de todos os tempos; e isso com o preciso escopo de que todos os homens tivessem a certeza de que são filhos de Deus e participantes de sua herança, como tão bem nos volta a lembrar Paulo: "E por que sois filhos, enviou Deus aos nossos corações o Espírito do seu Filho, que clama, Abba, Pai [...] E se és Filho, és também herdeiro, graças a Deus" (Gl 4,6-7). Nesse sentido podemos dizer que o Espírito Santo é o agente e a potência que faz com que o " $A b b a$ amado" de Jesus se torne também o "Abba amado" de cada cristão, uma vez que, através Filho, também somos constituídos em filhos de Deus.

A nossa condição de filhos de Deus e membros vivos do mistério da Igreja dá-se em virtude da nossa participação no mistério pascal de Cristo, somente tornada possível através do dom do Espírito Santo derramado em Pentecostes. Diante disso poderíamos, então, nos perguntar: O que significa, para nós, cristãos, a expressão "espiritualidade cristã”? Como é possível redes-

${ }^{3}$ Cf. JEREMIAS, J. “Abba”, Brescia, Paideia, 1968, p. 65; BOUTTIER, M. "L'Éxpérience du Père. L'Éxpérience du Fils. L'Éxpérience de l'Esprit: Jalons à partir du Nouveau Testament”. In: AA.VV., L'Éxpérience de l'Esprit, Le Point Théologique 18, Paris, Beauchesne, 1976, pp.15-45; FERLAY, P., Dieu, le Saint Esprit, Paris, Desclée de Brouwer, 1990, p. 67; O’DONNEL, J., Il Mistero della Trinità, Roma, Editrice Pontificia Università Gregoriana, Piemme, 1989, p. 55: "Gesù non solo percepì in modo del tutto particolare la relazione al suo Dio como Abba, ma anche ebbe coscienza di se stesso come portatore straordinario dello Spirito". 
cobrir e integrar a "espiritualidade cristã" com a presença e a ação do Espírito Santo na vida da Igreja? Em que sentido se pode afirmar que a vida da Igreja depende, fundamentalmente, da sua oração? Como, em última análise, inferir que a expressão "espiritualidade cristã", equivale, essencialmente a "espiritualidade litúrgica" ou "espiritualidade da Igreja"?

Sem pretender responder essas indagações, o que nos importa é enfatizar que a oração da Igreja e, em particular, a liturgia, é o ato constitutivo e essencial para a identidade eclesial em seu mistério mais profundo, tal como sempre entendeu a primitiva comunidade cristã e a sua tradição subsequente no pensar dos Padres da Igreja. Somos, dessa forma, desafiados a enfrentar uma tarefa de resgate e sábia atualização de um legado que a própria revelação bíblica nos confiou no que concerne precisamente ao tema da "espiritualidade cristã".

\section{A Espiritualidade Litúrgica como Espiritualidade da Igreja}

A situação pós-conciliar, no que concerne à liturgia católica, pode ser caracterizada por uma tensão bipolar Por um lado, verifica-se uma certa lentidão para se compreender e se aplicar pastoralmente alguns princípios fundamentais emanados da reforma litúrgica pós-conciliar. Dentre outras razões, isso pode acontecer devido à inclinação de se identificar o mistério da liturgia com um complexo conjunto de rubricas, herança de uma mentalidade predominante até o Concílio Vaticano II. Por outro lado, constata-se em nossos dias um sincero e ardente desejo de que a liturgia corresponda sempre mais às suas autênticas fontes e de que ela seja uma resposta profética de Deus para o homem de hoje.

Não se pode ignorar que redescobrir o tema do mistério da liturgia foi, para o Concílio Vaticano II, uma árdua e sofrida tarefa; e o mesmo se dá, incontestavelmente, em nossos dias, para a reflexão teológica em geral e para a teologia litúrgica em particular. Ao longo de cinco décadas aproximadamente realizou-se na vida da Igreja um valioso trabalho, tanto no plano teológico como pastoral, em vista de se redescobrir a autêntica natureza e o significado da espiritualidade litúrgica: referimo-nos ao assim chamado "Movimento Litúrgico", fenômeno eclesial e teológico iniciado nos inícios do século XX, envolvendo vários países e ambientes cristãos; seu cujo escopo precípuo era a busca de uma renovação profunda da vida espiritual da Igreja ${ }^{4}$.

${ }^{4}$ A respeito do ambiente e das necessidades que suscitaram o Movimento Litúrgico, conferir: TRIACCA, A.M., "La Partecipazione Litúrgica”. In: AA.VV., "Mystérion” nella Celebrazione del 
Um dos resgates mais fecundos realizado pelo Concílio Vaticano II, certamente devido ao Movimento Litúrgico, foi a reafirmação do tema da espiritualidade litúrgica como o eixo e âmago da vida da Igreja. Isso se pode constatar claramente na célebre intuição do Concílio, que afirmou ser a liturgia o "cume e a fonte" de toda a vida da Igreja: "Todavia, a liturgia é o cume para o qual tende toda a ação da Igreja e, ao mesmo tempo, é a fonte donde emana toda a sua força" (SC 10)5.

Essa genial intuição do Concílio encontra-se contextualizada no âmbito da teologia da revelação, e, mais precisamente, numa ótica histórico salvífica. Por isso é que a Constituição Litúrgica Sacrosanctum Concilium insiste em salientar a necessidade de a teologia contemporânea resgatar a dimensão econômico-salvífica da revelação e da liturgia. Tal procedimento do Vaticano II fundamenta-se essencialmente na teologia bíblica e na teologia litúrgica dos Padres da Igreja. Assim se pode entender o por quê da Sacrosanctum Concilium fazer a leitura do mistério da liturgia no contexto mais amplo de toda a história da salvação - a esse respeito basta conferir os números de 5 a 13, quando o documento trata da natureza da liturgia e de sua importância na vida da Igreja.

Ao longo de seu ministério messiânico, Jesus Cristo realizou plenamente o desígnio salvífico de seu Pai. Assim procedendo, ele levou a termo, após o

\footnotetext{
Mistero di Cristo nella Vita della Chiesa, Torino, Elle di Ci, 1981, pp. 264-265: "Laccentuata presa di coscienza che la maniera migliore di vivere il cristianesimo e di sentirsi ed essere chiesa è quella di vivere la liturgia con le modalità della partecipazione, a vari livelli, porterà i liturgisti dapprima alla formazione del clero su questa lunghezza d'onda. Dal clero formato a partecipare alla liturgia si arriverà al popolo che vi partecipa progressivamente e rinnovatamente. Di qui l'esplosione di iniziative tutte incentrate sulla questione della partecipazione liturgica, come congressi o settimane di studi, o pubblicazioni di diverso genere intese a far recepire, per mezzo di unadeguata catechesi liturgica, la necessita di una partecipazione vera e autentica alla liturgia". ${ }^{5}$ Cf. ibidem, p. 280: "Certo, l'azione liturgico-sacramentaria é "puntualizzata" nel tempo della celebrazione. Non avviene così alla realtà sacramentaria che ha un "prima" celebrativo e un "poi" celebrativo, nel quale é trasfusa e perdura l'efficacia e gli effetti della celebrazione. Si comprende allora come la partecipazione liturgica sia comprensiva di una più vasta gamma di realtà, tutte concentrate nella partecipazione allazione liturgica. Laggettivo attiva, che da Pio X alla Enciclica Mediator Dei, alla Costituzione liturgica del Concilio Vaticano II é attribuito alla partecipazione, risulta importantissimo se lo si comprende attribuito non solo alla partecipazione all'azione liturgica, ma coesteso alla partecipazione liturgica. È ivi incluso il superamento di visuali dicotomizzanti il rito dalla vita. In effetti il principio contenuto nella Sacrosanctum Concilium art. 10, dove é asserito che la liturgia é "culmen et fons", induce a farci comprendere che l'agire cristiano e l'essere cristiano é frutto dell'azione liturgica. Si potrà forse arrivare a comprendere che esiste un principio unificatore dell'agire cristiano, una realtà che é alla base di ogni azione e attività del fedele, che ne alimenta la costanza e la fedeltà, e che esso sia da ritrovare nella participatio liturgica?".
} 
longo tempo das promessas, o projeto amoroso de Deus em relação aos homens: referimo-nos ao mistério pascal da sua paixão e glorificação. Em virtude desse mistério o Espírito de Pentecostes foi enviado aos os apóstolos, pois somente assim é que estariam capacitados a proclamar, em todos os tempos e lugares, o mistério do amor que venceu a morte e de "realizar" esse mesmo mistério, e, isso, particularmente, através da celebração da liturgia. Isso só pode ser devidamente compreendido se considerarmos a própria promessa de Jesus, o qual garantiu estar permanentemente com a sua Igreja até a consumação dos séculos (cf. Mt 28,20). De fato, o Senhor Jesus está sempre presente e atuante em sua Igreja através da potência do Espírito Santo, mormente através das ações litúrgicas, conforme tão bem nos recorda a Constituição Litúrgica (cf. n. 7).

Parece-nos que o Concílio Vaticano II conseguiu demonstrar que, de acordo com a mais genuína concepção da Igreja, a espiritualidade litúrgica é, de fato, a espiritualidade da toda a Igreja e que a sua meta é a edificação renovada do Corpo de Cristo $^{6}$. Além do mais, segundo as conseqüências inferidas do pensamento conciliar, não deveria haver qualquer discrepância ou contraposição entre a espiritualidade litúrgica e as diversas expressões espirituais que enriquecem e compõem o patrimônio eclesial.

Na Igreja, com efeito, cada expressão da espiritualidade cristã deveria ter como fundamento e paradigma a obra salvífica realizada através do mistério pascal de Cristo, do qual todos os fiéis são chamados a participar ativa e plenamente: "Deseja ardentemente a mãe Igreja que todos os fiéis sejam levados àquela plena, cônscia e ativa participação das celebrações litúrgicas" (SC 14). Ainda que seja uma riqueza para a Igreja a existência de várias "escolas de espiritualidade", todas elas são insistentemente convidadas a se inspirarem na revelação bíblica, da qual emana a vida da Igreja e a sua espiritualidade. Necessário se faz também lembrar que a Igreja tem uma espiritualidade própria recebida de Cristo e da Igreja apostólica. Essa espiritualidade é a vida litúrgica.

Ao propor o mistério da liturgia como "cume" e "fonte" de toda a vida da Igreja e, por conseguinte, da espiritualidade cristã, o Vaticano II é incisivo em sugerir que se promova em todos os âmbitos da vida eclesial uma verdadeira educação litúrgica dos batizados, a fim de que eles tendam a uma maturidade de fé que se explicita na participação cada vez mais plena e ativa dos mistérios

\footnotetext{
${ }^{6}$ Cf. MAGGIANI, S., "Celebrare - Participare: Per un Pieno Coinvolgimento nel Mistero Celebrato". In R. FALSINI, (org.), I Laici nella Liturgia: Un Popolo Sacerdotale nel Dinamismo dell'Azione Liturgica, Milano, Edizioni O.R., 1987, pp. 72-106.
} 
cristãos. Essa maturidade é alcançada na medida em que a fé pessoal se fundamenta e se integra à fé da Igreja, uma vez que a espiritualidade litúrgica possui um caráter de apelo à decisão pessoal da fé e, simultaneamente, traz consigo uma herança que o próprio Senhor confiou ao seu corpo místico.

Segundo a experiência cristã dos primórdios, a espiritualidade cristã deverá sempre encontrar na celebração litúrgica a sua consistência e envergadura máxima. Isso significa dizer que o cristão somente poderá plenamente tomar parte nas maravilhas salvíficas operadas por Deus se lhe for franqueada a porta do encontro com o Cristo, o que somente é possível pela ação do Espírito Santo operante na Igreja e no mistério de seu culto. Um dos saldos mais positivos da integração entre a espiritualidade litúrgica e as diversas modalidades de espiritualidades que o Espírito tem suscitado, sobretudo nesses últimos anos do pós-Concílio, é que ela produz um movimento de convergência entre fé pessoal e liturgia, numa dupla forma de aquisição: a fé ou espiritualidade pessoal, sempre que brota e se desenvolve a partir da liturgia, passa a adquirir uma estrutura medular que não apenas a consolida como também lhe possibilita a descoberta de formas criativas e expressivas sempre renovadas. Por outro lado, a espiritualidade litúrgica, que se expressa maximamente no culto, redescobre, quando posta em contato com as variadas moções espirituais da vida cristã, suas nervuras vitais e o alcance sempre novo de seus potenciais e versatilidade. O que naturalmente a impede de se esclerosar em fórmulas sem vida ou num rubricismo improlífero? ${ }^{7}$.

\section{A Trinitariedade da Espiritualidade Litúrgica}

A espiritualidade litúrgica, por sua natureza, quer ser um processo plasmático que, gradativamente, conduz o homem à meta daquilo que é a essência da

\footnotetext{
${ }^{7}$ Cf. SODI, M., "Liturgia: Pienezza e Momento della Storia della Salvezza”. In AA.VV., "Mystérion" nella Celebrazione del Mistero di Cristo nella Vita della Chiesa, Torino, Elle di Ci, 1981, pp. 143-144: "La Liturgia non è una devozione speciale, che si propone scopi speciali, il cui raggiungimento segna il grado di penetrazione della nuova devozione. È qui ancora lo scoglio ordinario di molti, della maggior parte. Della pietà liturgica si è sempre fatto a meno, se ne può ancora fare a meno [...] La Liturgia è la pietà nell'economia del Nuovo Testamento. Così, senz’altro. Assoluti? Esagerati? - Assoluti, sì; esagerati, no [...] La liturgia non è una forma di pietà da preferirsi, per la ragione forse che meglio corrisponde alla nostra natura di uomini (essere sociali) e alla nostra qualità di cristiani, di esseri cioè appartenenti a una società soprannaturale. La Liturgia nella vita del cristiano rappresenta un valore assoluto, che merita tutta l'attenzione possibile, perché incarna vorrei dire, la sua vita spirituale stessa, quella per cui é cristiano [...]”; cf. KOSER, C., "Piedade Litúrgica e "Pia Exercitia" à Luz da Constituição Litúrgica”. In G. BARAÚNA (org.), A Sagrada Liturgia Renovada pelo Concílio, Petrópolis, Vozes, 1964, pp. 203-249.
} 
vida cristã: viver em Cristo por meio de uma vida segundo o Espírito (cf. Gl 2,20; 5,16). Em vista de tal escopo, a experiência cristã brota dos sacramentos celebrados e neles se alicerça e se desenvolve - e aqui queremos enfatizar de modo privilegiado os sacramentos da iniciação cristã. A vida sacramental, nesse sentido, não cessa de se tornar, na existência de cada batizado, uma fonte de experiência de Deus que tem a capacidade de se atualizar e renovar nas celebrações litúrgicas, especialmente quando elas contam com uma participação consciente e frutuosa.

Antes de mais nada, é necessário salientar que a espiritualidade litúrgica possui uma dimensão trinitária, o que significa dizer que ela é teocêntrica, cristológica e pneumática. Esta dimensão trinitária da espiritualidade litúrgica só é devidamente compreendida se não perdermos de vista o seu aspecto econômico-salvífico ${ }^{8}$.

Segundo a mais antiga práxis da Igreja - e aqui pensamos de modo particular na teologia dos Padres da Igreja - a dimensão trinitária da espiritualidade litúrgica se expressa, em âmbito cultual, pela fórmula "per Filium in Spiritu Sancto ad Patrem" ("pelo Filho, no Espírito ao Pai"). O que está em jogo aqui não é apenas uma fórmula cultual, mas, antes de mais nada, uma profissão de fé trinitária haurida da oração da Igreja, sendo aqui oportuno recordar que tal oração sempre foi tida como a norma para o estabelecimento dos dogmas e da fé pessoal dos fiéis.

É essencial que se documente isso, pois já no IV século encontramos um clássico axioma atribuído a Próspero de Aquitânia: "Legem credendi lex statuat suplicandi" ("A lei da oração estabelece a lei do crer" - sendo "lei da oração" aqui entendida como a oração da Igreja ou oração litúrgica). O pensamento de Próspero, certamente, não é algo de isolado ou pessoal; ao contrário, expressa com clareza o modo como a Igreja vivia e testemunhava a sua fé por meio da ars celebrandi (arte de celebrar) e da ars vivendi (arte de viver, de testemunhar). Segundo o nosso autor, é na celebração litúrgica que o dom da fé e dos enunciados dogmáticos são devidamente explicitados e professados. Dessa forma, o dogma deve sempre estar aberto ao mistério do culto, nele encontrando perene fecundidade e jovialidade. Abertas à colaboração dinâmica da celebração litúrgica as verdades dogmáticas, sempre mais serão iluminadas em sua compreensão, bem como melhor assimiladas pelas comunidades dos crentes. $\mathrm{O}$ dogma e a liturgia nesse profícuo intercâmbio possibilitarão à Igreja uma crescente e dinâmica compreensão de si mesma, em especial no que diz respeito ao seu mistério e à sua missão.

\footnotetext{
${ }^{8}$ GRANADO, C., "El Don del Espíritu en S.Hilario de Poitiers”, Estudios Eclesiásticos 57 (1982), pp. 433, 440-441, 443.
} 
A dimensão essencialmente trinitária do mistério da liturgia pode ser comprovada pelo seguinte fluxo dinâmico que dá origem e que perpassa os textos utilizados nas celebrações litúrgicas, habitualmente chamados de "textos eucológicos": "Do Pai, pelo Filho, no Espírito, ao Pai". Trata-se daquilo que poderíamos denominar de "manancialidade trinitária", o que é suficiente para demonstrar o quanto a práxis cúltica da Igreja, desde as suas origens, teve uma nítida consciência de fé na profissão trinitária de Deus. Tanto a tradição litúrgica do Oriente como do Ocidente nos colocam em contato com a herança legada pelos apóstolos e pelos Padres da Igreja, a qual testemunha o cunho trinitário das ações litúrgicas, em especial da celebração eucarística9.

Em realidade, a liturgia é "gloria ao Pai, pelo Filho, no Espírito Santo", síntese cúltica que exprime o núcleo do plano salvífico do Pai: memória da obra redentora realizada pelo Cristo e atualizada na Igreja pelo dom do Espírito Santo. O Verbo encarnado é o centro vivente da liturgia prestada ao Pai. O Pai, por vez, é a sua origem primeira e o seu termo último. O Espírito Santo, entretanto, é quem faz com que o louvor do Cristo ao Pai seja comunicado à Igreja.

A partir da revelação econômica da Trindade podemos inferir que o "Evento-Cristo" marca o momento culminante da História da Salvação, a partir do qual brota para o homem a possibilidade de um encontro e de uma experiência real com Deus. Cristo Jesus, "caminho" para o Pai, é também o "eventomistério", o "sacramento de encontro" com Deus, segundo a célebre intuição de E.Schillebeeckx. Perfazendo essa dimensão cristológica da revelação, consignamos ser o Espírito Santo o agente que possibilita continuar e atualizar ininterruptamente na Igreja a presença do Cristo ressuscitado como "sacramento de salvação"; não sem razão o Jesus pré-pascal foi peremptório ao afirmar que o Consolador o glorificaria e continuaria sua obra (cf. Jo 14,16). Somente no Espírito, por conseguinte, pode-se reconhecer e professar o "senhorio" de Jesus (cf. 1Cor 12,3) e somente n'Ele é que temos acesso ao Pai por meio de Cristo (cf. Ef 2,18).

A celebração cristã ganha o seu selo de autenticidade exatamente porque é toda convergente "ao" Pai, "por" Cristo, "no" Espírito Santo; através do Filho $^{10}$. Na força do Espírito podemos nos aproximar do Pai e com Ele travar

\footnotetext{
${ }^{9}$ LAMBIASI, F., Lo Spirito Santo: Mistero e Presenza, Bologna, Dehoniane, 1987, p. 248.

${ }^{10}$ Cf. VALENTINO, A.M., L'Esperienza di Dio nei Temi dei Grandi Sacramentari e del Messale Romano di Paolo VI, Dissertatio ad Doctoratum Sacrae Liturgiae Assequendum in Pontficio Instituto Liturgico, Roma, 1990, pp. 258-259: "La celebrazione cristiana è tale perché fatta "per" Cristo "nello" Spirito. Tramite il Figlio, nella "dýnamis" dello Spirito Santo, noi possiamo
} 
uma experiência de vida e comunhão. Assim, a liturgia, em sua ontologia, outra coisa não é senão a celebração-atuação do desígnio de Deus realizado pelo "Mistério-Cristo", "no" e "por" obra do Espírito Santo.

O fim último da revelação bíblica é fazer com que cada homem "conheça" Deus e d'Ele "faça experiência". Tendo sido levada a termo a antiga lei mosaica, na nova economia é por meio de Jesus Cristo que nos vêm a "graça e verdade" e é "de sua plenitude que todos nós recebemos a graça por graça" (Jo 1,16-17). Gerada e manifestada pela graça de Deus, que é o próprio Espírito, a Igreja se autocompreende como o Corpo vivificante de Cristo tecido na história humana. Consciente de sua fragilidade, ela é, nessa última etapa da economia salvífica, o "lugar" e o instrumento da salvação e experiência de Deus para todos os homens mediante o "sacramento" do culto divino.

Longe de ser uma mera metafísica especulativa, o mistério da Trindade foi vivido, desde a mais remota experiência da Igreja, como um acontecimento celebrativo que fora capaz de plasmar a profissão de fé da Igreja e de cada fiel, o que se pode constatar já no querigma apostólico e nas comunidades cristãs da primeira hora. Atualizando essa herança bíblica, o Concílio Vaticano II, ao abordar o tema da liturgia no seu fulcro celebrativo, o contextualiza no plano histórico-salvífico da revelação, sobrelevando, dessa forma, a sua dimensão trinitário-econômica (cf. SC 6).

\section{A Espiritualidade da Igreja é uma "Mística Sacramental"}

O tema da experiência de Deus, segundo o que verificamos até aqui, está em estreita relação com o da espiritualidade cristã, de tal forma que, caso queiramos nos manter na perspectiva neotestamentária, não podemos falar de um sem levarmos em consideração o outro. É de grande relevância para a reflexão teológica contemporânea aprofundar a mútua relação que existe entre o fenômeno da experiência de Deus e a sua carga expressiva no campo da espiritualidade.

\footnotetext{
"avvicinarci" al Padre. Nell'“economia penultima" - il Tempo della Chiesa -, questo è l'ambito" nel quale (e a partire dal quale) è possibile l'“esperienza" di Dio. La liturgia non è altro che la celebrazione-attuazione del Mistero di Cristo "nello Spirito Santo e per opera dello Spirito Santo". Pertanto, se per "incontrare" il Padre è necessario "passare" per il Figlio (cf. Gv 14,6b), per "entrare" nel Mistero del Figlio (che rivela il Padre) bisogna "essere guidati" dallo Spirito Santo (cf. Gv 16,1315), nel quale, d’altronde, si è "riconosciuti" figli dal Padre (cf. Rm 8,14-16)".
} 
Relevante e extremamente atual para a teologia cristã da atualidade é também o despertar do interesse e da sensibilidade pela dimensão mística da vida humana em suas mais variadas formas e modalidades. O renascimento e a redescoberta do sagrado e da sede pelo mistério e pela mística, indubitavelmente, poderão encontrar a sua plena cidadania e o seu "lugar" mais legítimo na "Igreja-Mistério" e na celebração dos "mistérios" da Igreja. Tal ensejo se fundamenta no fato de que a Igreja cristã, desde as suas origens, se manifesta no mundo como um "organismo místico", uma "mística pessoa", conforme tão bem assinalou o teólogo alemão Heribert Mühlen" ${ }^{11}$ Como tal, o "Corpo de Cristo", segunda a proposta da "teologia somática" proposta pelo apóstolo Paulo, não pode não ser o "lugar teofânico" da revelação plena do Deus vivo e verdadeiro na história e no mundo.

O Espírito Santo era, no pensar dos Padres da Igreja, o agente que plasmava a mística cristã e o cristão-místico. Na realidade, em virtude de sua própria natureza batismal, o cristão sempre foi considerado, segundo a tradição patrística, como um místico, isto é como alguém qualificado e capacitado a tomar parte nos "mistérios" celebrados pela Igreja - e com "mistérios" entendemos aqui os sacramentos da fé cristã. Importante ainda é salientar que, segundo essa tradição, o conceito de "espiritualidade" nada tinha de genérico e abstrato, e muito menos dizia respeito a experiências meramente personalistas ou subjetivistas da fé. Em geral, quando usavam o termo "mystérion", os Padres pensavam na vida litúrgica que sempre acontecia graças à fé que o próprio Senhor transmitiu à sua Igreja ${ }^{12}$. Dessa mesma fé é que nasce e

${ }^{11}$ Heribert Mühlen, célebre teólogo alemão nascido em 1927, publicou em 1967 o clássico tratado eclesiológico Una Mystica Persona. Ali Mühlen procura abordar o mistério da Igreja em chave penumatológica. As obras de Mühlen têm sido de grande contributo para o aprofundamento da pneumatologia pós-conciliar, mormente no que diz respeito à Igreja - cf. Idem, Una Mystica Persona, Roma, Città Nuova, 1968; Idem. "El Concepto de Dios. Nuestra Época necesita un Punto de Partida Pneumatológico-Trinitario", Estudios Trinitarios 6 (1972), pp. 535-559; Idem, "Espíritu Santo y la Iglesia - Relación entre Sacramento y Carisma", Estudios Trinitarios 9 (1975), pp. 385-399; Idem, Experiencia Social del Espíritu como Resposta a una Doctrina Unilateral sobre Dios. In C.HEITMANN, - H.MÜHLEN, (orgs.), Experiencia y Teologia del Espíritu Santo, Secretariado Trinitario, 1978, pp. 339-363.

${ }^{12}$ Em síntese, esta era a compreensão de "mystérion" na Patrística dos primeiros séculos cristãos: 1) Embora o termo seja usado numa acepção análoga ao uso do Novo Testamento, há já nos inícios da Patrística, uma conotação eclesial mais marcante que aquela das comunidades neotestamentárias; 2) "mystérion" encontra sua atuação e expressão na Igreja, sempre relacionando-se e ligado ao âmbito da "celebração"e do "culto" cristão; 3) O Mistério terreno da Igreja é uma atuação do mistério celeste, do qual é sinal, símbolo. As diversas manifestações da vida da Igreja, sobretudo nos Sacramentos, são prolongamento e conseqüência do mistério celeste. Relacio- 
matura a vida cristã, o que só se torna possível em virtude de uma adesão pessoal e uma assimilação existencial do dado objetivo da fé. Por isso é que, com freqüência, observamos nas catequeses patrísticas, de conteúdo litúrgico-sacramental, uma certa insistência de o batizado jamais descuidar do equilíbrio a ser mantido entre os dados objetivo e subjetivo da fé.

A "mística sacramental" - e esse é um dos maiores legados da teologia dos primeiros séculos da fé cristã - tem a sua gênese na livre e gratuita iniciativa de Deus que, por todos os meios, não cessa de ir ao encontro do homem para salvá-lo. Somente com o mistério pascal do Verbo encarnado é que se dá, segundo a economia da revelação, a plena realização do desígnio amoroso e salvífico de Deus. Ao homem, doravante, caberá, também de forma livre e gratuita, responder a tal desígnio divino, o que, à luz da práxis cristã primitiva, se dá, privilegiadamente, no contexto cúltico-celebrativo; isso faz com que a base da experiência de Deus seja fundamentalmente sacramental ou "mistérica", e disso parece que as primeiras comunidades cristãs eram bastante conscientes.

Herdeiros da experiência espiritual da Igreja neotestamentária e patrística, estamos habilitados a afirmar que a espiritualidade de Igreja ou espiritualidade cristã é, simultaneamente, cristológica, pneumática e sacramental e, por isso mesmo, "mistérica". O mistério de Cristo encarnado e ressuscitado, sempre vivo e presente pela ação do Espírito Santo, é o conteúdo nuclear de nossas celebrações eclesiais. Nesse sentido o Concílio Vaticano II sugere-nos com plausibilidade que o mistério pascal de Cristo, clímax da obra salvífica de Deus, torna-se presente e se atualiza na vida dos crentes, de forma privilegiada, através do culto divino, e isso em forma de celebração e experiência mistérico-sacramental (cf. LG 7; GS 22; SC 5; SC 22).

A liturgia, enquanto mystérion, é o lugar no qual Cristo, em toda a sua vida e obra, torna-se presente para unir-se intimamente a todos os membros de sua Igreja e torná-los "participantes da natureza divina" (cf. 2Pd 1,4). A liturgia possui um papel determinante no que diz respeito a essa "participação", uma vez que nela subjaz uma "economia sacramental", particularmente no que se refere ao papel dos sacramentos do batismo e da eucaristia. Ativado pelo convite de Deus - o da participação em sua vida de comunhão - o cristão é instigado a respondê-lo livremente, a ele aderindo em forma de resposta cultual. Ora, o culto divino, como "espaço místico" por excelência

nados a "mystérion", encontramos ainda outros termos, alguns dos quais bastante usados pelos Padres no que concerne ao campo da celebração dos Sacramentos e da espiritualidade cristã ou da experiência de Deus. 
na existência cristã, vem a ser um "misterioso sinal", a partir do qual torna-se possível a concretização de um projeto de comunhão, que diz respeito tanto a Deus quanto ao homem.

Sabemos que a expressão "mística sacramental" não é muito comum na linguagem teológica corrente. Todavia, é de nosso interesse demonstrar o fundamento sacramental da mística cristã e a esteira de continuidade que existe entre a economia sacramental da Igreja e a vocação mística de que é chamado a viver cada batizado na fé e na celebração da Igreja. Para uma adequada releitura da liturgia e da celebração dos sacramentos em perspectiva mística, devemos, mais uma vez, nos apropriar daquela feliz imagem que o Concílio Vaticano aplica à liturgia como sendo o "cume e a fonte" de toda a vida da Igreja e, portanto, da mística cristã. Toda a economia da salvação e, de modo particular, a economia sacramental e litúrgica se constituem numa fecunda tessitura, lugar da dinâmica e contínua ação de Deus; a "mística sacramental", nessa linha, outra coisa não é senão a participação, em nível eclesial e pessoal, nas grandes obras de Deus, evocadas, celebradas e vividas.

O termo "mística", oriundo do mundo helenista e das religiões de mistério, foi assumido pela fé cristã e associado ao mistério pascal de Cristo e à experiência dos sacramentos, também chamados de "mistérios". Desde então esses mistérios, celebrados pela Igreja e experimentados pelos fiéis como os sinais distintivos da vida em Cristo, foram testemunhados como a síntese das "maravilhas" realizadas por Deus ao longo de toda a história da salvação. A virgem Maria, por exemplo, como autêntica representante do povo do primeiro testamento, faz ecoar em si o canto de todos os seus antepassados: "O Poderoso fez em mim maravilhas e Santo é o seu Nome" $(\operatorname{Lc} 1,49)$.

Os sacramentos, como síntese e viva expressão das "maravilhas" operadas por Deus, celebradas no tempo da Igreja e atualizadas no coração dos fiéis, se relacionam diretamente com o que a fé cristã entende, segundo a sua tradição com a vida mística da Igreja e de seus membros. "Mística", nesse sentido, quer, então, significar a experiência que os batizados são chamados a fazer do Deus vivo através dos "mistérios", isto é, dos sacramentos, por meio de uma participação viva e ativa, ainda que percebida apenas pela fé. Isso porque as realidades inauguradas pelo Cristo, mediante o seu mistério pascal, podem agora tornar-se "misticamente" presentes em virtude da ação do Espírito Santo que age em cada ato litúrgico-sacramental celebrado pela Igreja. Analogamente, o termo "místico" ("mystikós") diz respeito à identidade do Corpo Místico de Cristo e a cada cristão; a todos membros de Cristo, o "mistério 
escondido desde os séculos em Deus" (Ef 3,9) é agora anunciado, comunicado e celebrado nos mistérios sacramentais da Igreja. Essa acepção de "mística" e "místico" é retomada por alguns teólogos do século XX, dentre os quais L.Bouyer é um exímio representante; segundo ele, a noção de "mystikós", em seu sentido original, havia sido extraída da revelação bíblica, e encontrava a sua aplicação concreta nos âmbitos litúrgico e espiritual ${ }^{13}$.

É de nosso interesse destacar aqui o fundamento litúrgico-sacramental e o "lugar" celebrativo da espiritualidade e da mística cristã. Sendo essencialmente sacramental, a mística cristã brota, amadurece e se consuma no ambiente vital da liturgia e dos sacramentos, aos quais somos introduzidos desde o momento em que efetivamente passamos a formar o Corpo Sacramental de Cristo. A vida mística cristã vem a ser, portanto, a gestação contínua da vida do Ressuscitado nos cristãos. Por meio dos sacramentos da iniciação, os batizados começam um itinerário de crescimento rumo à "unidade da fé e ao pleno conhecimento do Filho de Deus, o estado de Homem perfeito, à medida da estatura da plenitude de Cristo" (Ef 4,13). Em outros termos isso significa que, conforme o projeto de Deus, o homem é chamado a se deixar "cristificar" a fim de se humanizar plenamente.

A mística cristã se radica profundamente na vida sacramental; esta, por sua vez, não pode atingir o seu pleno desenvolvimento senão na fecundidade da esfera mística cultivada por aquele que se nutre dos sacramentos; é a integração do "sacramental-místico" que nos faz atingir a plenitude da revelação sacramental. A rica tradição da espiritualidade cristã nos testemunha que a referida integração encontrou concretamente o seu lugar na existência de vários místicos, os quais aprenderam a fazer da "lei da oração" a "lei do crer". Através de seus testemunhos constamos ser possível a cada cristão viver autêntica e plenamente a sua fé batismal.

Com efeito, somente através da essência da mística batismal, isto é, de uma ativa consciência de fé na ação da presença trinitária em nós, é que podemos experimentar e testemunhar as maravilhas realizadas por Deus e que, nos sacramentos, são atualizadas e continuamente renovadas ${ }^{14}$. A experiência

${ }^{13}$ Cf. ROCCHETTA, C., La Mistica del Segno Sacramentale. In: E.ANCILI-M.PAPAROZZI (orgs.), La Mistica, Fenomenologia e Riflessione Teologica, Roma, Città Nuova, Vol II, 1984, p. 49: "L.Bouyer ha opportunamente mostrato come in origine l'aggettivo mystikós implicasse tre significati strettamente interdipendenti tra loro: biblico, liturgico e spirituale. Biblico: mystikós corrisponde al significato profondo delle Scritture, significato nascosto e accessibile solo nella fede della Chiesa”.

${ }^{14}$ Cf. JOÃO PAULO II, Encíclica Redemptoris Missio, Petrópolis, Vozes, 1991, n. 24: “A missão 
mística, por sua vez, confere à liturgia todo o seu realismo no momento em que os sinais sacramentais transformam-se em experiência celebrada, vivida e testemunhada. A mística cristã, nesse sentido, traz em si mesma a capacidade de projetar a luz da fé nos sacramento, revelando-nos plenamente a fecundidade dos mesmos.

A partir desses pressupostos estamos em condições de superar a tendência, tantas vezes presente em nossa práxis de fé, que é precisamente a de considerar a oração litúrgica e a vida mística como duas retas paralelas ou como realidades antagônicas. Isso é totalmente inaceitável para a espiritualidade cristã, uma vez que a economia sacramental e a fertilidade mística se complementam e se realizam interativamente, a ponto de uma realidade não subsistir sem a outra. É tarefa da espiritualidade cristã aprofundar a relação recíproca entre a celebração litúrgica e a vida mística cristã, relendo na mesma perspectiva a sacramentalidade da Igreja e os sacramentos em particular.

\section{Conclusão}

O intuito da nossa exposição foi o de mostrar a necessidade e a urgência de se resgatar, tanto na reflexão teológica como na práxis cristã, a íntima relação que sempre existe entre a liturgia e espiritualidade dos batizados. O que nos motiva a tal empreendimento é a fecunda e sempre atual proposta do Concílio Vaticano II, precisamente compendiada na afirmação, por nós já salientada, de que a liturgia é a "fonte e o cume" de toda a vida da Igreja. Tal proposta, profundamente inspirada na revelação bíblica e na tradição da Igreja, pede por ser continuamente retomada, aprofundada e atualizada; e essa é uma tarefa que compete de modo particular à reflexão teológica. Numa espécie de diálogo permanente, a teologia sistemática, a teologia bíblica e a teologia litúrgica são convocadas a lançar um profundo olhar sobre essa proposta do Concílio, sempre abertas a se deixar surpreender pelos novos caminhos que certamente ela poderá

da Igreja, tal como a de Jesus, é obra de Deus, ou, usando uma expressão freqüente em S.Lucas, é obra do Espírito Santo. Depois da ressurreição e ascensão de Jesus, os Apóstolos viveram uma intensa experiência que os transformou: o Pentecostes. A vinda do Espírito Santo fez deles testemunhas e profetas (cf. At 1,8;2,17-18), infundindo uma serena audácia, que os leva a transmitir aos outros a sua experiência de Jesus e a esperança que os anima. O Espírito deu-lhes a capacidade de testemunhar Jesus sem medo". 
nos apontar. Quanto mais penetrarmos nos meandros dessa proposta conciliar, mais ficaremos estarrecidos com os seus desdobramentos e com as inúmeras aplicações que ela poderá nos oferecer em vários níveis.

A partir de uma saudável teologia pneumática somos conduzidos a inferir que a espiritualidade litúrgica, desde os primórdios cristãos, foi experimentada e traduzida na catequese como a espiritualidade da Igreja. De cunho essencialmente trinitário, foi essa espiritualidade que desde sempre modelou a experiência de fé dos cristãos e deu envergadura ao testemunho que eles deveriam dar diante do mundo.

Como herdeiros de uma experiência e de um testemunho de fé que perpassaram os séculos e que foi resgatada, de modo único e privilegiado, pelo Concílio Vaticano II, cabe-nos a tarefa de abraçar e aprofundar com seriedade o tema da espiritualidade litúrgica. Tal tarefa já se constitui, certamente, como um importante contributo que a Igreja pode oferecer ao mundo de hoje, tão aberto às várias dimensões do Transcendente e do Sagrado.

\section{Referências Bibliográficas}

BOUTTIER, M., “L'Éxpérience du Père. L'Éxpérience du Fils. L'Éxpérience de l'Esprit: Jalons à partir du Nouveau Testament". In: AA.VV., L'Éxpérience de l'Esprit, Le Point Théologique 18, Paris, Beauchesne, 1976, pp. 13-45.

FERLAY, P. Dieu, le Saint Esprit, Paris, Desclée de Brouwer, 1990.

GRANADO, C., "El Don del Espíritu en S.Hilario de Poitiers. In: Estudios Eclesiásticos 57 (1982), pp. 429-450.

JEREMIAS, J., “ $A b b a ”$, Brescia, Paideia, 1968.

JOÃO PAULO II, Encíclica Redemptoris Missio, Petrópolis, Vozes, 1991.

KOSER, C., "Piedade Litúrgica e "Pia Exercitia" à Luz da Constituição Litúrgica". In: G.BARAÚNA (org.), A Sagrada Liturgia Renovada pelo Concílio, Petrópolis, Vozes, 1964, pp. 203-249.

LAMBIASI, F., Lo Spirito Santo: Mistero e Presenza, Bologna, Dehoniane, 1987, p.248. 
MAGGIANI, S., "Celebrare - Participare: Per un Pieno Coinvolgimento nel Mistero Celebrato". In R.FALSINI, (org.), I Laici nella Liturgia: Un Popolo Sacerdotale nel Dinamismo dell'Azione Liturgica, Milano, Edizioni O.R., 1987, pp. 72-106.

MÜHLEN, H., "El Concepto de Dios. Nuestra Época necesita un Punto de Partida Pneumatológico-Trinitario", Estudios Trinitarios 6 (1972), pp 535-559.

,"Espíritu Santo y la Iglesia - Relación entre Sacramento y Carisma", Estudios Trinitarios 9 (1975), pp. 385-399

,"Experiencia Social del Espíritu como Resposta a una Doctrina Unilateral sobre Dios". In: C.HEITMANN - H.MÜHLEN, (orgs.), Experiencia y Teologia del Espíritu Santo, Secretariado Trinitario, 1978, pp. 339-363.

, Una Mystica Persona, Roma, Città Nuova, 1968.

O’DONNEL, J., Il Mistero della Trinità, Roma, Editrice Pontificia Università Gregoriana, Piemme, 1989.

PANIMOLLE, S.A., "La Adorazione di Dio in Spirito e Verità". In: AA.VV., Spirito Santo e Liturgia - Atti della XII Settimana di Studio dell'Associazione Professori di Liturgia, Valdragone (S.Martino), 22-26 agosto 1983, Casale Monferrato, Marietti, 1984, pp.11-22.

ROCCHETTA, C., "La Mistica del Segno Sacramentale". In: E.ANCILI M.PAPAROZZI, (orgs.), La Mistica, Fenomenologia e Riflessione Teologica, Roma, Città Nuova, Vol II, 1984.

SAGRADA CONGREGAÇÃO PARA O CULTO DIVINO, Instrução Geral à Liturgia das Horas, Rio de Janeiro, Lumen Christi, 1982.

SODI, M., Liturgia: "Pienezza e Momento della Storia della Salvazza". In: AA.VV., "Mystérion" nella Celebrazione del Mistero di Cristo nella Vita della Chiesa, pp. 115-152.

TRIACCA, A.M., "La Partecipazione Liturgica". In: AA.VV., "Mystérion" nella Celebrazione del Mistero di Cristo nella Vita della Chiesa, Torino, Elle di Ci, 1981, pp. 261-287. 
VALENTINO, A.M., L'Esperienza di Dio nei Temi dei Grandi Sacramentari e del Messale Romano di Paolo VI, Dissertatio ad Doctoratum Sacrae Liturgiae Assequendum in Pontficio Instituto Liturgico, Roma, 1990.

\section{Luiz Fernando R. Santana}

Doutor em Teologia pela PUC-Rio

Professor do Departamento de Teologia da PUC-Rio

Professor do Instituto Superior de Teologia da Arquidiocese do Rio

Artigo Recebido em 16/02/2012

Artigo Aprovado em 16/04/2012 